\title{
RESEARCH PHILOSOPHY IN DEVELOPMENT STUDIES: AN INQUIRY FROM QUALITATIVE DESIGN
}

\author{
Sapkota, Mahendra ${ }^{13}$
}

\begin{abstract}
Development studies have got both discourse as well as empirical field of research. This paper presents a synthesis of research methodology and its philosophical settings in the field. It deals with philosophical and methodological approaches from the qualitative research design approach. Then it offers a methodological plural perspective along with the discussion of interpretivism, criticalism and social constructivism. Though this paper is not developed out of an empirical field study, the methodology here employed is the review based reflexive perspective of the author. Discussing the context of grounded theory approach, the paper illustrates how a position of the researcher and the conditionality of the study universe affect each other. The central argument of the paper maintains that in multi-real world the disciplinary approach and single-method inquiry could not go into the depth of the research world. Rather, the realties are complex and often changing rapidly in the given political economic context of development. It is thus a time to look after the methodological approach of development studies.
\end{abstract}

Keywords: Development Studies, Epistemology and Ontology, Interpretivism, Criticalism, Methodological Pluralism, Social Constructivism, Social Science Research, Study Universe

\section{Background: Philosophical Positions of the development study}

Why a philosophy is important in research? How does it contribute to the research and generation of knowledge? Is it simply an exercise of human intelligence to know the existing reality of being or it's also a matter of transformation into a better future? These discussions lead us to the next area for consideration, which Blaikie (2009) describes as the 'research paradigm' and by others (Saunders, Lewis \& Thornhill, 2009) as the 'research philosophy'. Some of them also maintain it as 'worldview' (Creswell, 2013). These philosophies are formed from basic ontological and (the related) epistemological positions, and have developed in both classical and contemporary forms to effectively classify different research approaches. Denzin and Lincoln (2013) describe a research paradigm as 'an interpretive framework' and in borrowing from Guba (1990), as a 'basic set of beliefs that guides action'. In a similar tone, Saunders, Lewis and Thornhill (2009) assert 13 Dr. Sapkota is affiliated to Tribhuvan University (Central Department of Rural Development, Faculty of Humanities and Social Sciences), and Yunnan University (School of Ethnology and Sociology). Corresponding Email: sapkota.mahendra27@gmail.com 
Research Nepal Journal of Development Studies (Year $2^{\text {nd }}$ Issue $1^{\text {st }}, 2019$ May)

that research philosophy is an over-arching term relating to the development of knowledge and the nature of that knowledge. For Babbie (2015) it is a comprehensive belief system, world view, or framework that guides research and practice in a field (p. 8). In the general classification, there are three key paradigms - those of positivist (classical), interpretivist/ constructivist (classical) and realist/ critical (contemporary). All the paradigms then engage with the fundamental questions of ontology (what is the nature of reality, being or existence?), epistemology (what is the acceptable knowledge in a field of study/ universe?), axiology (what are the values and meanings inserted?) and methodology (how we can approach with the reality and knowledge?).

Development studies has become a multi-disciplinary branch of social sciences, where philosophy/ ideology and practices/ implications go hand in hand (see Sumner, \& Tribe, 2008; Desai, \& Potter, 2013). The researchers of development studies, however, contrast with the idea of normal paradigm or discourse. Metaphysically, all the paradigms are misleading towards absolute truth and noble reality (Robson \& McCartan, 2016), and they do not match to the theories and approaches of development studies (Pieterse, 2010). They have further promoted methodological determinism as they wrongly suggest that the three paradigms are mutually exclusive and that they represent the totality of possible research approaches. Rather than accepting this paradigm definition of research, recent concerns in development research have followed a paradigmic pluralism thereby saturating the knowledge from empirical finding to the theory generation. It eventually becomes what many scholars call 'methodological pluralism in the multi-real world. Going to the real 'world' and giving the concluding remarks with 'words' is indeed a challenging task. This is one of the emerging trends of development research, though has been less theorized. To reflect Della Porta (2013):

Indeed, methodological pluralism seems to dominate the field. While a narrative that is widespread in several subfields in the social sciences tends to present a Manichean picture, pitting positivist versus interpretivist (hermeneutics) views, social movement scholars tend to develop more nuanced views... suggesting that some of its main characteristics have favored the development of methodological pluralism, with a dialogue between different epistemological approaches and frequent triangulations of methods (p. 9).

Yet, there are some challenging issues in linking the search on development studies and rural studies. The methodological determinism or absolutism is the fundamental challenge in this regard. This is simply because no any kinds of social events (such as the movement, agitations and development interventions) could happen in isolation with the mode of homogenization 
Sapkota, Mahendra

that could be generalized everywhere and forever. Rather, they are a larger manifestation of collective behavior of people within the society. A research design for the study of contestation in rural development, then, includes various interrelated elements that reflect its sequential nature. Methodologically, this stands with two perspectives. First, the researcher has (and should have) knowledge of the current issues and discourse, in particular the ideological construct of development. Second, the methodological implications would relate to the study to those issues and discourses as evident in literature review and subsequent findings which could synthesize the findings of any rural/ developmental studies. Following this assumption, the researcher can have a methodological pluralism to view the multi-real and multi-local research universe (Table 1).

Table 1: Summary of methodological positions and research design

\begin{tabular}{|c|c|c|}
\hline & Approach & Rationale \\
\hline Ontology & Social constructivism & $\begin{array}{l}\text { - Social roots of development and its } \\
\text { multiple implications; multi-locality of } \\
\text { the research universe }\end{array}$ \\
\hline Epistemology & $\begin{array}{l}\text { Interpretivism and } \\
\text { Criticalism }\end{array}$ & $\begin{array}{l}\text { Subjective (non-material well- } \\
\text { being, identity issues, aspirations) of } \\
\text { development } \\
\text { Objectivity (material well-being, } \\
\text { outcomes in development activities and } \\
\text { local service delivery) }\end{array}$ \\
\hline $\begin{array}{c}\text { Methodological } \\
\text { approach }\end{array}$ & Qualitative & $\begin{array}{l}\text { - Contestations, power relations, and } \\
\text { development 'world' }\end{array}$ \\
\hline $\begin{array}{l}\text { Theoretical } \\
\text { approach }\end{array}$ & Grounded Theory & $\begin{array}{l}\text { - Inductive approach to the contestation; } \\
\text { construction of micro-narratives of } \\
\text { development on the ground; need of } \\
\text { theorization and conceptualization }\end{array}$ \\
\hline & Emergent design & - $\quad$ Based on the nature of Grounded Theory \\
\hline Research design & $\begin{array}{l}\text { Case study of the } \\
\text { rural / community } \\
\text { development }\end{array}$ & $\begin{array}{l}\text { - Large socio-cultural and political } \\
\text { coverage, and one of the powerful } \\
\text { movement in Tarai }\end{array}$ \\
\hline
\end{tabular}

Source: 


\section{Objectives and Methodology}

This paper presents a synthesis of research methodology and its philosophical settings in the field of qualitative research on development studies. It deals with philosophical and methodological approaches from the qualitative research design approach. Then it offers a methodological plural perspective along with the discussion of interpretivism, criticalism and social constructivism. Though this paper is not developed out of an empirical field study, the methodology here employed is the review based reflexive perspective of the author. Discussing the context of grounded theory approach, the paper illustrates how a position of the researcher and the conditionality of the study universe affect each other

\section{Discussions: Epistemological position}

Though the studies on rural/ community development have grown enormously in recent years, there has been comparatively less engagement for methodological and philosophical debates, particularly in epistemological issues and paradigms. Globally, different methodological approaches sought to discern and analyze the social and cultural process through which meanings and identities are formed and deformed in in the given contexts of power relations. In recent years, the cultural turn in both development practices, policies and academia has unsettled the domains in all the major school of thoughts involving Marxist, post-, neo-, and non-Marxist approaches in the development studies. Therefore, the researcher could position herself/himself for the development of methodological pluralism, with a creative interaction with different epistemological approaches and triangulations of methods. This is, indeed, a journey with a passion and challenge what Escobar and Alvarez assert as an 'involvement of a complex epistemological process' (1992, p. 6).

Most of the development studies often begin with 'interpretive' word view. Unlike the positivist ideas of natural sciences, it switches on subjective realities, as interpreted by the interaction between the researcher (the outsider) and research participants (the insider). Society is subjective in nature; it is experienced and structured as we behave and give meaning upon it. Meaning therefore is constructed and (over time) constantly re-constructed through experience resulting in many differing interpretations. It is these multiple interpretations that create a social reality in which people act in multiple ways (DeLyser \& Sui, 2013). Reviewing these conceptual insights, a researcher of development studies can encounter to a question about the subjective nature of social events- the power relations in particular. Further, the relation between researcher and the researched (people/ stakeholder/ rural development) seems also important to view how the realities are constructed. The researcher's focus then goes on the understanding of meanings and 
interpretations of social actors or relationships that constructed the contestation in development with the rise and fall of different strategies or ideological interventions. This epistemology seems highly contextual to view the subjective realities within the local community context and the nonmaterial well-being of rural people.

However, some researchers (e.g. Bryman, 2012; Fay, 1993; Henn, Weinstein \& Foard, 2009) critically observed that knowledge about the social world is a complex whole of the historical, social and political contexts beyond the simple interpretation of the social world. Society does live with the realism of truths, and the realism is conditioned by the objectivity. Does development follow this? If the development is a contested notion, development could have both subjective constructions/ deconstructions as well as objective realities/ dialectics. With this, then, a development researcher can follow 'criticalism' in order to supplement interpretivist epistemology.

The critical research approach is highly influenced by critical theoretical foundation for what Willis (2007) maintains that it tends to 'emphasize relationships that involve inequities and power, and a desirable aspect of critical research involves helping those without power to acquire it' ( $p$. 82). For the researchers, it would rather contribute to creating a discourse, not being confined within the subjective interpretation of local narratives and grassroots realities. Critique over the ideology of the development has been another rationality of the selection of critical perspective on many of the development researches. In doing this, there could have a risk of gradual shifting of his/her academic research persona into an activism like a political activist, probably nearer to a common criticism of critical research, as being supported a political agenda (Hammersley, 1995). Instead, the researcher should be aware of the argument that this is a necessary consequence because politics and inquiry are intertwined or inseparable and, by having an agenda of reform, all participants' lives can be transformed for the better world (Creswell, 2013).

The researchers in development studies, therefore, argue that the production of knowledge is not a linear, monolithic and one-dimensional process. Rather, it is dialectical in nature which could be synthesized from interpretivism and criticalism. The nexus of both the subjective and objective realities is complex though, which makes the content of 'pure research' more problematic. Without the interpretivist investigation, it is impossible to penetrate the objective reality in depth to understand its essential nature and changing dynamics of society in general and its development process in particular. It is therefore both types of realities are subject of investigation for the social science researchers, which truly implies in case of the development studies. To put Engles:

The fact that our subjective thought and the objective world are subject to the same laws, and hence too, that in the final analysis they cannot contradict each other in their results, 
but must coincide, governs absolutely our whole theoretical thought (Engels, 1883; as quoted by Woods \& Grant, 2007, p. 349).

Methodologically, this dialectic has been justified in different issues of development research, both empirically and theoretically. The issues may range from the methodological domains of rural livelihood, community development, gender relations, women studies, poverty and inequality, rural political economy, development planning, rural-urban linkage, local leadership, local governance, subaltern studies, etc. with the observation of subjective reality (interpretivism) and objective reality (criticalism). Further, the dialectics between subjective reality and objective reality has been described as a kind of epistemological triangulations, which can also contribute to increase the trustworthiness of the study proposed/ accomplished.

\section{The continuum of ontology and methodology}

There is a dynamic and informed relationship between epistemology, ontology, methodology and methods. Some interpretivist researchers methodologically oriented towards a social constructivist approach (constructivism) and focus on the collaborative process of bringing about meaning and knowledge (Black, 2006; Elliott \& Lukes, 2008). In development studies, most of the researchers follow an ontology of constructivism, which assumed contestation in the development process (ideology/practice) as a social phenomenon and its meanings are continually being accomplished by social actors and forces within the society. In other words, the basic idea to follow constructivism is that the rise of contestations in development is a 'social construction' being produced and developed through a dynamic interaction of different means, forces and relationships in the society. Under the constructive ontology the study can proceed with grounded approach, which is methodologically inductive, i.e. moving from specific ground (particular reality/ case) to the universal knowledge (theory) system of the world. The contestations are thus assumed to be collective realities shaped by the particular context of history, politics and economy.

As discussed by various scholars in Nepal and abroad (e.g. Gesier, 2014; Manandhar, 2011; Sapkota, 2017), the contemporary research in development studies is juxtaposed with a consecutive 'contestation'. These attributes could be observed in the given context, though they are hardly measurable and quantifiable. The nature of the development and aspirations of people is itself a qualitative manifestation along with considerable reflexibility, contextuality and fluidity. With this constructivism, researches on development/ rural studies can follow a qualitative approach. Theoretically, it is useful when a phenomenon is observed thoroughly, but needs to be understood as to why the phenomenon is or how the phenomenon came to be. Qualitative methods commonly exist as five approaches including case studies, narratives (hermeneutics), phenomenologies, 
ethnographies and grounded theories (Berg, Lune \& Lune, 2004; Charmaz, 2008; Creswell, 2013; Patton, 1990, 2005).

As a particular attribute of qualitative approach, grounded theory is one strategy which follows multiple data sources to a same phenomenon by making a constant comparison, saturation and consequently, a theorization (Corbin \& Strauss, 2014; Glaser, 2005; Strauss \& Corbin, 1990). Earlier writings of Juliet Corbin and Anselm Strauss (1990) did not focus grounded theory as a methodological package; but their latest writing (e.g. in 2008) explained pragmatism and symbolic interactionism as the philosophies of grounded theory. Conversely to Strauss and Corbin, Glaser has refuted any kinds of philosophical position arguing that such positions can reduce the broader potential of grounded theory. However, Glaser can be generally cited as the critical realist within the post-positivist paradigm. More recently, grounded theory approach has been described with a constructivist approach, which is referred as "constructivist grounded theory" (Bryant \& Charmaz, 2019). It is not simply to record changes in its appearance or phenomenal form, but to reveal the nature of the relationship between the development issues and underlying contradictions. Thus, the development research can also follow this grounded methodological approach with the constructivist ontological position. It is thus assumed that neither data nor theory are discovered, but are constructed within the given contexts of the phenomena and interaction.

\section{Research Design}

The term "research design" is less common in qualitative research due to the semi-structured, flexible and subjective nature of the studies. Punch (1998) very nicely states that it is the research design that situates the researcher in the empirical world, and connects the research questions to data. Postmodern theorists and scholars argue that research design is not linear, but rather a circular or cyclical which involving constantly emerging contexts and upheavals in the study universe. This type of methodological approach inclined to a qualitative approach of in-depth study. Many researchers (e.g. Babbie, 2007; Bryman, 2008; Flick, 2009) argue that qualitative research design is particularly applicable in in-depth studies based on interpretative epistemology and constructive ontology. Most of the movement researchers and scholars of rural studies also argue for the applicability of qualitative approach, because contestations within the human society or its problems are often conditioned by social relationships. Thus, the studies on development are popularly followed a qualitative methodology that can encompass complexity of historical, political, social and economic issues.

Assuming the study problem as a social event, the study then can follow an in-depth case study of the research universe. Yin (2009) defines the case study research design as "an inquiry that 
Research Nepal Journal of Development Studies (Year $2^{\text {nd }}$ Issue $1^{\text {st }}, 2019$ May)

investigates a contemporary phenomenon within its real-life context" (p. 79). For Ragin and Becker (1992), the aim of case study is the precise description or reconstruction of an event or issue. According to Mills, Durepos and Wiebe (2010), only a few texts deal directly with case studies as a central subject and no encyclopedic reference provides a thorough overview of the design and methods in case study research as a guidance for students, researchers, and professionals who are trying to incorporate case studies into a rigorous research project or program ( $\mathrm{p} . \mathrm{xxxi}$ ).

Contrarily, some scholars also maintain that the case studies are misunderstood as a type, as well as a method, of qualitative research (Gerring, 2004, p. 341). Because of its holistic nature of the study, some researchers argue that the case study research methodology is best suited to the study that takes critical and interpretive epistemology (Elliott \& Lukes, 2008) - which also seems quite relevant in the present study context. Though there can be various development issues in the country (from local to federal/ capital), the case study of particular research components (individual person, organization, leadership, movement, etc) is best assumed for answering the research questions of contested development, potentially because of its larger coverage, diverse setting and intensifying trend. The particular case would make the study more focused, typical and instructive to address the research problems. Thus, the case should be selected purposively, theoretically and holistically. Furthermore, the researcher can do some cross-case studies (of institutions or information-rich participants) in the field, as s/he needs so in analyzing the research findings and theorizing them

\section{Grounded Theory Approach}

Though in a very few contexts of development research, grounded theory has been now become as the most challenging inductive approach. It has been rooted with the ontology of constructivism. The grounded approach was originally developed by Glaser and Strauss as "a general methodology of analysis linked with data collection that uses a systematically applied set of methods to generate an inductive theory about a substantive area" (Glaser \& Strauss, 1967, p. 63). Though grounded theory has been developed as an encompassing research strategy in the social sciences since 1970s, still it has been rarely regarded in development studies. Many scholars and researchers (e.g. Mattoni, 2013) have argued that grounded theory is particularly applicable in analyzing grassroots contentious politics, social change and movement activism. Mattoni (2013) in particular suggests that the grounded theory contributes to enrich the empirical findings as well as shaping the theoretical issues in the cases where political actors are involved in social processes. 
Grounded theory is quite different from the traditional model of research, where the researcher chooses an existing theoretical framework, and only then collects data to show how the theory does or does not apply to the phenomenon under study (Allan, 2003). In contrast to theorydriven and linear model of the research process, the grounded theory gives priority to the data and the field under study over theoretical assumptions. As a few research works (and in case of Grounded theory) of development research are not following or imposing any particular theory to the subject being studied, his/her attempt is to theorize empirical data to be found in it. In subsequent way, codes are created, then the codes form concepts, and the concepts form categories. Among the categories, few core categories are constructed and they ultimately lead to a theory building process. It could be possible only by understanding the construction of meanings and realities from the point of local people and finally through discovering a theory implicit in the data. Empirically, it has focused on the contestation on development studies from the lens of the meanings, perceptions, identities, well-being and expectations from and of the research universe.

The grounded theory is essentially a constructive approach, and not an 'empiricism' of local realities. The field reflections also indicate that ground realities are diverse and could not be measured empirically. In doing so, it could not negate or disregard the traditional or existing theories. The researcher could have thus some distinct observations regarding why and how s/ he adopted this grounded methodology in particular, and not others. The first and basic point of departure in the studies is the lacks and gaps in the scientific and theoretical explanations of contested issues of development. Instead, there are some questions resulted and unanswered from earlier research works. The third background for applying grounded theory can be rapidly changing contexts of movements and the emergence of various issues. The change of rural development regime (paradigms and approaches) is also complex and less articulated to the statesociety relations. Accordingly, the grounded approach can be guided with constructivist ontology as proposed initially in positioning this research project. Finally, the researcher's personal motivation and interest also work to go with the rural people, to be native and to make research questions explicitly oriented towards the theoretical world.

\section{Researcher's positioning on the Empirical World}

The position of researcher is a crucially important dimension of research to shape and manifest the epistemological and methodological issues. In development studies, this is also true. The researcher's position in his/ her research is often guided by two factors: a) the researcher's perception of social science and the world of reality (emic/etic); and b) the reflections on the identities of researchers (outsider or etic) vs. researched (insider or emic). Though cultural 
Research Nepal Journal of Development Studies (Year $2^{\text {nd }}$ Issue $1^{\text {st }}, 2019$ May)

anthropology and ethnographic studies largely adapt the emic and etic approaches, contemporary research on development studies also increasingly following them. Development is both an exogenous and an endogenous process; and it the process ultimately leads to a cultural product. How people behave and how they form the realities of society (emic) is more important though it can be equally affected with the outsider world of researchers and stakeholders (etic). The emic approach investigates how local people think, as how they perceive and categorize the world, their rules for behavior, what has meaning for them, and how they imagine and explain things. Contesting this, the etic approach shifts the focus from local observations, categories, explanations, and interpretations to those of the researchers (Kottak, 2006).

These two factors come to affect the empirical world of the research in the development studies where qualitative approaches (including participatory and ethnographic) have been followed. Though the researcher is a single person and the research site is another single attribute, both are interwoven to manifest the knowledge at large, as reflected in Table 2.

Table 2: Researcher's position and conditionality of the study universe

\begin{tabular}{|l|l|}
\hline \multicolumn{1}{|c|}{ Researcher's position } & \multicolumn{1}{c|}{ Universe conditionality } \\
\hline - Where and when the researcher born? & $\begin{array}{l}\text { Site, location and topographic } \\
\text { situation of the study site/ } \\
\text { community/ settlement }\end{array}$ \\
$\begin{array}{l}\text { Native language of the researcher, and } \\
\text { his/her sexual, caste/ ethnic and religious }\end{array}$ & $\begin{array}{l}\text { Caste/ ethnic structure, religious } \\
\text { gelonging } \\
\text { - Social prestige and well-being status of the } \\
\text { researcher }\end{array}$ \\
$\begin{array}{l}\text { Background of school education, university } \\
\text { degree (place, discipline, faculty and } \\
\text { department) }\end{array}$ & $\begin{array}{l}\text { social control systems, socio-cultural } \\
\text { organizations and status of well- } \\
\text { being in the community }\end{array}$ \\
$\begin{array}{l}\text { Particular political ideology of the } \\
\text { researcher, or his/ her platform of activism } \\
\text { and advocacy or any }\end{array}$ & $\begin{array}{l}\text { livelihood structure/ practices, } \\
\text { production systems and economic } \\
\text { organization/ institutions in the study } \\
\text { area }\end{array}$ \\
$\begin{array}{l}\text { Profession of the researcher, if any other } \\
\text { than University faculty or student? }\end{array}$ & \begin{tabular}{l} 
\\
\hline
\end{tabular}
\end{tabular}

Source:

Indeed, the researcher could not change the objective reality of the universe or study site but s/ he can interpret the world in accordance his/ her personal subjective feelings/ constructs and 
Sapkota, Mahendra

objective realities what does s/he belong to now. Conversely, both the objective and subjective realities of study universe cannot change the reality of the researcher, though the researcher's worldview can be transformed along with living conditions, socio-cultural systems, and local narratives. This further leads to a theoretical saturation of the research. Doing this, the researcher can try to incorporate somehow his/ her personal academic background, research experiences and gaps, and valuable insights learned from the people of the study site. It is often said that in most of social sciences, the researchers need to keep an 'impartiality' in the research issues or problems. However, but a critical researcher of development studies can maintain 'neutrality' still in favor of those people who are suffering from the existing power relations within the society, i.e. poverty, dependency, inequality, marginalization, elitism and other contradictions.

\section{Conclusion}

As a researcher is a social product of the existing society, the research work itself is a part of this social world. In most of the qualitative studies in development research, the researcher's primary goal is an understanding of social processes and contexts rather than obtaining a representative sample in statistical terms. Indeed, such studies are intended for a knowledge generation and contribution to the 'study universe' at global level. The nature of knowledge is representative, reflexive and explorative with time, space and actors. Social science research is also a part of this reflexivity. Vedanta literatures of eastern philosophy maintain that knowledge (Gyan/Vidhya) is a supreme service to the science, which comprises of Sat (being), Ananta (eternal) and Ananda (blissful). The question is how to make a part of that science and be representative of that knowledge. Development studies, has, thus to be linked into this research approach.

\section{References}

Allan, George (2003). A critique of using grounded theory as a research method, Electronic Journal of Business Research Methods, vol. 2, no. 1 (2003) pp. 1-10.

Babbie, E. (2007). Research methods in sociology. New Delhi: Ceneage Learning.

Babbie, E. R. (2015). The practice of social research. Birchmount Rd, Scarborough, ON M1K 5G4, Canada: Nelson Education.

Berg, B. L., Lune, H., \& Lune, H. (2004). Qualitative research methods for the social sciences (Vol. 5). Boston, MA: Pearson.

Black, I. (2006). The presentation of interpretivist research. Qualitative Market Research: An 
International Journal, 9(4), 319-324.

Blaikie, N. (2009). Designing social research. London: Polity Press.

Bryant, A., \& Charmaz, K. (Eds.). (2019). The SAGE Handbook of Current Developments in Grounded Theory. SAGE Publications Limited.

Bryman, A. (2008). Social research methods in organization studies. New York: Oxford University Press.

Bryman, A. (2012). Social research methods. Oxford: Oxford university press.

Charmaz, K. (2008). Constructionism and the grounded theory method. Handbook of constructionist research (pp. 397-412). New York: the Guilford Press

Corbin, J. \& A. Strass (2014). Basics of qualitative research: Techniques and procedures for developing grounded theory ( $4^{\text {th }}$ edition). Thousand Oaks: Sage Publications.

Creswell, J. W. (2013). Research design: Qualitative, quantitative, and mixed methods approaches ( $4^{\text {th }}$ edition). London: Sage publications.

Della Porta, D. (2013). Methodological practices in social movement research. Spring term workshop (April 15-18, 2013), Badia Fiesolana, Italy.

Delyser, D., \& Sui, D. (2013). Crossing the qualitative-quantitative chasm III: Enduring methods, open geography, participatory research, and the fourth paradigm. Progress in Human Geography, 2 (38), 294-307 (print published 1 April, 2014). doi: https://doi. org/10.1177/0309132513479291

Denzin, N. K., \& Lincoln, Y. S. (2013). Collecting and interpreting qualitative materials (Vol. 3). London: Sage Publications.

Desai, V., \& Potter, R. B. (2013). The companion to development studies. London: Routledge.

Elliott, J. and Lukes, D. (2008). Epistemology as ethics in research and policy: The use of case studies. Journal of Philosophy of Education, 42(S1), 87-119.

Escobar, A., \& Alvarez, S. (1992). Introduction: Theory and protest in Latin America today. The making of social movements in Latin America: Identity, strategy, and democracy, pp. 1-15. USA: American Sociological Association 
Fay, B. (1993). The elements of critical social sciences. In M. Hammersley (Ed.), Social research: Philosophy, politics and practice, 33-46. London: Sage

Flick, U. (2009). An introduction to qualitative research (4 ${ }^{\text {th }}$ Edition). New Delhi: Sage.

Geiser, U. (2014). Conceptualising 'contested development' - from grand narratives to the nittygritty of the everyday. In S.R. Sharma, B.R. Upreti, P. Manandhar, \& M. Sapkota (Eds), Contested Development in Nepal: Experiences and Reflections (pp. 1-25). Kathmandu: School of Arts, Kathmandu University and Nepal Centre for Contemporary Research (NCCR).

Gerring, J. (2004). What is a case study and what is it good for? The American Political Science Review, 98, Issue 2, pp. 341-354. Inštitut za slovenski jezik Frana Ramovša ZRC.

Glaser, B. G. (2005). The grounded theory perspective III: Theoretical coding. CA: Sociology Press.

Glaser, B. S., \& Strauss, A. (1967). The discovery of grounded theory: Strategies for Qualitative research (reprinted in 2006 and 2009). New York: Aldine. Retrieved from http://www. sxf.uevora.pt/wp-content/uploads/2013/03/Glaser 1967.pdf

Guba, E. G. (Ed.). (1990). The paradigm dialog. Newbury Park, CA: SAGE.

Hammersley, M. (1995). The politics of social research. London: Sage.

Henn, M., Weinstein, M., \& Foard, N. (2009). A Critical Introduction to social research ( $2^{\text {nd }}$ edn). New Delhi: Sage.

Kottak, Conrad (2006). Mirror for Humanity, p. 47. McGraw-Hill, New York. ISBN 978-0-07$\underline{803490-9}$.

Manandhar, P. (2011). Contested Rural Development in Nepal. Working paper for the research project (NCCR N-S RP1) on 'contested rural development', No. 32, Bern and Zurich, Switzerland: NCCR N-S.

Mattoni, A. (2013). The potentials of grounded theory in the study of social movements. A working paper, April 15-18, 2013), Badia Fiesolana, Italy.

Mills, A. J., Durepos, G. and Wiebe, E. (2010). Encyclopaedia of case study research. London: Sage. 
Research Nepal Journal of Development Studies (Year $2^{\text {nd }}$ Issue $1^{\text {st }}, 2019$ May)

Patton, M. Q. (1990). Qualitative evaluation and research methods. London: SAGE Publications.

Patton, M. Q. (2005). Qualitative research. New York: John Wiley \& Sons, Ltd.

Pieterse, J. N. (2010). Development theory. London: Sage.

Punch, M. (1998). Politics and ethics in qualitative research. In N. Denzin, \& Y. Lincoln (Eds.), The landscape of qualitative research: Theories and practices (pp. 156-184). London: Sage.

Ragin, C. C., \& Becker, H. S. (Eds.). (1992). What is a case? Exploring the foundations of social inquiry. London: Cambridge university press.

Robson, C., \& McCartan, K. (2016). Real world research. New York: John Wiley \& Sons.

Sapkota, M. (2017). Rise of ethnic movements and contested development in Nepal: A case study of the Tharu movement. An unpublished PhD Thesis, Kathmandu University, School of Arts, Kathmandu, Nepal.

Saunders, M., Lewis, P., \& Thornhill, A. (2009). Understanding research philosophies and approaches. Research methods for business students, 4, 106-135.

Strauss, A., \& Corbin, J. (1990). Basics of qualitative research. London: Sage publications.

Sumner, A., \& Tribe, M. A. (2008). International development studies: Theories and methods in research and practice. Sage.

Willis, J. W. (2007). Foundations of qualitative research: Interpretive and critical approaches. Thousand Oaks, CA: Sage Publications.

Woods, A., \& Grant, T. (2007). Reason in revolt; Marxist philosophy and modern science. New Delhi: Aakar Books.

Yin, R. (1994). Case study research: Design and methods. Beverly Hills. 